\title{
RATING OF INDOOR ENVIRONMENTAL QUALITY IN SYSTEMS OF SUSTAINABILITY ASSESSMENT OF BUILDINGS
}

\begin{abstract}
Indoor environmental quality (IEQ) has an important impact on health and wellbeing of building users. In order to maintain an acceptable IEQ, policies, strategies and guidelines on achieving the required IEQ have been developed. Control and evaluation of indoor air factors is needed for ensuring the sufficient air quality. Impact of emmisions from building materials, furnishings and HVAC systems to indoor air quality should be included in the assessment of indoor environmental quality. In many systems for sustainability assessment of buildings is put a great emphasis on indoor environmental quality. This paper provides an overview of sustainability assessment systems for rating of indoor environmental quality. The criteria included in LEED, BREEAM and other well known systems for assessment of indoor environmental quality are presented. Building environmental assessment system (BEAS) developed for application in Slovakia is also introduced. Worldwide used rating systems were based on the development of BEAS. This is multi-criteria system contained six main fields such as site selection and project planning; building construction; indoor environment; energy performance; water and waste management. System consist from 53 indicators of assessment.
\end{abstract}

Keywords: Indoor environment, sustainability assessment of buildings, BEAS

\section{Introduction}

According to study [1], the concentration of indoor air pollutants varies significantly in different environmental conditions. During recent years several studies have been performed targeting towards the assessment of indoor air quality in selected places. Increasing rate of industrialization and urbanization, especially in developing countries, has led to increase of air pollution levels as well as increased concern about air pollution impact on human health [2].

\footnotetext{
${ }^{1}$ Author for correspondence: Silvia Vilcekova, Vysokoskolska 4, 04200 Kosice, Slovakia, +421556024260, silvia.vilcekova@tuke.sk

${ }^{2}$ Eva Kridlova Burdova, Vysokoskolska 4, 04200 Kosice, Slovakia, +421556024125, eva.kridlova.burdova@tuke.sk.
} 
Indoor air quality (IAQ) is one of the major contributors to disease burden in the world [3, 4]. Those members of the population who are more susceptible to the effects of poor air quality, the elderly, the very young and those of ill health, will spend a greater amount of time indoors [5] probably in the home, than an average member of the population. It is therefore important to determine whether the quality of air inside a home is affected by changes in outdoor concentrations and to determine the sources of pollutants within the domestic environment [6]. Well-being is an important aspect determining the quality of life of an occupant. In late 1980s and during the 1990s, the WHO concept of health, became significant for identifying the concept of a "healthy building" in terms of building performances (i.e. indoor air quality, thermal comfort, lighting and acoustics) [7]. Indoor environment is a significant field in building environmental assessment system (BEAS) developed in Slovakia in the last few years. The main fields and indicators of BEAS are based on the analysis of worldwide used sustainable assessment systems and methods such as LEED, BREEAM, SBTool, and DGNB and so on. These sustainable building rating tools emphasize the importance of paying attention to indoor environmental quality throughout the design, construction as well as operation of buildings. Monitoring and evaluation of indoor air pollutants occurred is important for proposal of indicators in the field of indoor environment. Evaluation of indoor environmental quality generally includes physical parameters, chemical compounds and biological pollutants. Analysis of occurrence of selected pollutants in residential buildings was used for proposal of indoor environmental indicators. The percentage weights of indicators were determined depending up the level of indoor pollutants occurrence as well as the extent to which exceeded the permissible values.

This paper provides an overview of sustainability assessment systems for rating of indoor environmental quality. The criteria included in BREEAM, LEED and other well-known systems for assessment of indoor environmental quality are presented. Building environmental assessment system (BEAS) developed for application in Slovakia is also introduced.

\section{Systems for assessment of indoor environmental quality}

Building environmental assessment systems aim at considering the three aspects of sustainability of buildings: environmental issues such as greenhouse gas emission and energy consumption, economic aspects such as investment and equity and social requirements such as accessibility and quality of spaces [8]. The main goals of sustainable design is to reduce depletion of critical resources like energy, water, and raw materials; prevent environmental degradation caused by facilities and infrastructure throughout their life cycle; and create built environments that are safe and productive [9]. Methods and systems for integrated evaluation of buildings are used for the purpose of pre-design, 
design, construction, operation, maintenance and end of life of sustainable buildings [10].

The first of such tools was in 1990 the Building Research Establishment Environmental Assessment Method (BREEAM) [11]. After that, other methodologies, such as the Comprehensive Assessment System for Building Environmental Efficiency (CASBEE) from Japan, the Building and Environmental Performance Assessment Criteria (BEPAC) from Canada, the Building Environmental Assessment Method (HK-BEAM) from Hong Kong, the Green Building Rating System (SABA) from Jordan, the Estidama from Emirate, the Sustainable Building Assessment Tool (SBAT) from South Africa and Deutsche the Gesellschaft für Nachhaltiges Bauen (DGNB) from Germany.

\subsection{BREEAM}

Building Research Establishment's Environmental Assessment Method (BREEAM) designated as the building environmental assessment method of choice at that time was developed in the United Kingdom in 1990. Health and wellbeing is a concept that has not been adequately addressed by BREEAM, which is mainly predominated by the requirements for energy conservation and air-tightness of buildings. This is especially true for the assessment of IAQ and thermal comfort issues, which are largely missing in BREEAM and the Code for Sustainable Homes of UK. Health and wellbeing is recognised as an important mark of quality in the Code for Sustainable Homes. The objective is that homes built according to the Code should provide a more pleasant and healthy place to live. As people spend about $90 \%$ of their time indoors their exposure to indoor air pollutants and IAQ should be a particular important issue

for assessment and as design criteria. Also pollutants such as formaldehyde and volatile organic compounds (VOCs) released in the homes can have an adverse impact on people's health. Buildings satisfying the requirements of BREEAM for air-tightness would potentially enhance the indoor concentrations of pollutants as well as the risk of proliferation of moulds in these buildings [14]. In the table 1 is shown main field in system BREEAM related to environmental quality of buildings $[12,13]$.

Table 1. Health \& Wellbeing in system BREEAM

Tabela 1. Zdrowie i Dobre Samopoczucie w systemie BREEAM

\begin{tabular}{|l|l|l|}
\hline Environmental sections & Assessment issues & Weighting \\
\hline \multirow{4}{*}{ Health \& Wellbeing } & Visual comfort & \multirow{4}{*}{$15 \%$} \\
\cline { 2 - 2 } & Indoor air quality & \\
\cline { 2 - 2 } & Thermal comfort & \\
\cline { 2 - 2 } & Water quality & \\
\hline
\end{tabular}




\subsection{LEED}

LEED (Leadership in Energy and Environmental Design) was developed and piloted in the U.S. in 1998 as a consensus-based building rating system. The development of LEED has been through the U.S. Green Building Council member committees. LEED is a third-party certification programme and the nationally accepted benchmark for the design, construction and operation of high performance green buildings. LEED promotes a whole-building approach to sustainability by recognizing performance in five key areas of human and environmental health, namely: sustainable site development, water savings, energy efficiency, materials selection and indoor environmental quality. LEED has a greater emphasis in the assessment of low emission materials used, indoor environmental quality (IEQ) and building management (before and after construction) including the maintenance of mechanical ventilation and HVAC system [14]. In Table 2 the checklist of IEA for the LEED 2009 system for new construction and major renovations project is shown $[12,15]$.

Table 2. IEQ in system LEED 2009 for new construction and major renovations project

Tabela 2. IEQ w systemie LEED 2009 dla projektów nowych konstrukcji i remontów generalnych

\begin{tabular}{|c|c|c|}
\hline \multicolumn{2}{|c|}{ Indoor Environmental Quality } & \multirow{2}{*}{\begin{tabular}{|l|}
15 Possible Points \\
Required
\end{tabular}} \\
\hline Prerequisite 1 & Minimum Indoor Air Quality Performance & \\
\hline Prerequisite 2 & \begin{tabular}{|llll}
$\begin{array}{l}\text { Environmental } \\
\text { Control }\end{array}$ & Tobacco Smoke & (ETS) \\
\end{tabular} & Required \\
\hline Credit 1 & Outdoor Air Delivery Monitoring & 1 \\
\hline Credit 4.1 & $\begin{array}{l}\text { Low-Emitting Materials-Adhesives and } \\
\text { Sealants }\end{array}$ & 1 \\
\hline Credit 4.2 & $\begin{array}{l}\text { Low-Emitting Materials-Paints and Coat- } \\
\text { ings }\end{array}$ & 1 \\
\hline Credit 4.3 & $\begin{array}{l}\begin{array}{l}\text { Low-Emitting Materials_-Flooring Sys- } \\
\text { tems }\end{array} \\
\end{array}$ & 1 \\
\hline Credit 4.4 & $\begin{array}{l}\text { Low-Emitting } \quad \text { Materials-Composite } \\
\text { Wood and Agrifiber Products }\end{array}$ & 1 \\
\hline Credit 5 & $\begin{array}{l}\text { Indoor Chemical and Pollutant Source } \\
\text { Control }\end{array}$ & 1 \\
\hline Credit 6.1 & Controllability of Systems_-Lighting & 1 \\
\hline Credit 6.2 & $\begin{array}{l}\text { Controllability of Systems - Thermal Com- } \\
\text { fort }\end{array}$ & 1 \\
\hline Credit 7.1 & Thermal Comfort-Design & 1 \\
\hline Credit 7.2 & Thermal Comfort-Verification & 1 \\
\hline Credit 8.1 & Daylight and Views-Daylight & 1 \\
\hline Credit 8.2 & Daylight and Views-Views & 1 \\
\hline
\end{tabular}




\subsection{BEAS}

In recent years the evaluation of building performance in terms of environmental, social and economic aspects has become a topic of discussion in the Slovak Republic, as well. The new building environmental assessment system (BEAS) has been developed at the Institute of Environmental Engineering, Technical University of Košice. The systems and tools used in many countries have been the foundation of the new system development applicable under Slovak conditions. The main fields and relevant indicators of BEAS have been proposed on the basis of available information analysis from particular fields of the building performance in Slovakia and also according to our own experimental experience. The manner and form of indicators evaluation is proposed according to the SBTool. The proposal of the main fields results from the quality of the outdoor and indoor environment, nature and landscape conservation, exploitation of natural resources and so on. Building construction is subject to environmental deterioration, hence the proposal of site selection and project planning field is valid in BEAS. In Slovakia, buildings are characterized by high energy consumption therefore their energy performance is also an important field of assessment. Selection of building materials and structures is very important in term of embodied energy and emissions of pollutants. The reasons for the proposal of these and other fields such as indoor environment, water and waste management are shown in the next sections. BEAS as a multi-criteria system includes environmental, social and cultural aspects. The proposed fields and indicators respect and adhere to Slovak standards, rules, studies and experiments. In this study, the presented system has been developed for the preliminary stages of the life cycle, i.e. pre-design and design. The developed assessment system for Slovakia contains 6 main fields and 52 indicators [12]. In the table is shown field Indoor environment in system BEAS.

Table 3. Indoor environment in system BEAS

Tabela 3. Środowisko wewnętrzne w systemie BEAS

\begin{tabular}{|l|l|l|}
\hline C & Indoor environment & $\mathbf{2 3 . 5 3 \%}$ \\
\hline C1 & Thermal comfort & 16.4 \\
\hline C2 & Humidity & 5.5 \\
\hline C3 & Acoustic & 12.7 \\
\hline C4 & Daylighting & 12.7 \\
\hline C5 & TVOC & 16.4 \\
\hline C6 & Indoor air quality & 5.5 \\
\hline C7 & Radon & 9.1 \\
\hline C8 & NOx & 5.5 \\
\hline C9 & PM10 & 14.5 \\
\hline C10 & Microbe & 1.8 \\
\hline
\end{tabular}




\section{Discussion}

Building environmental assessment is used to specify, predict and measure environmental performance in buildings, which can highlight long term operational benefits, provide a valuable marketing tool for the construction industry to increase demand for quality and promote corporate and public sector sustainability [16]. There are numerous mainly voluntary environmental assessment methods currently in use around the world and while methods of assessment vary in accordance with local circumstances and stakeholders' concerns, they do share characteristics and goals that are significant in their similarity [17]. Many countries either have or are in the process of developing domestic assessment methods, which makes the need for international exchange and coordination increasingly relevant [18]. In several studies suggest indoor environmental quality tool [19], evaluation model [20], classification index [21] or scheme [22] for evaluating indoor environmental quality. Study [23] state that most of the buildings the sustainability assessment system does not include a good social and economic sustainability principles, even though they have different accents, but tend towards resources and environmental criteria and at the same time to dominate the socioeconomic problems and weighting credits and in the final assessment have also ambiguities and shortcomings. This paper provides an overview of sustainability assessment systems for rating of indoor environmental quality by introduction an approach environmental assessment of building. Study [24] showed that there is still no single best tool for assessing sustainability. In the figure 1 is shown significant weights in percentage of main field in system used over the world related to indoor environmental quality.

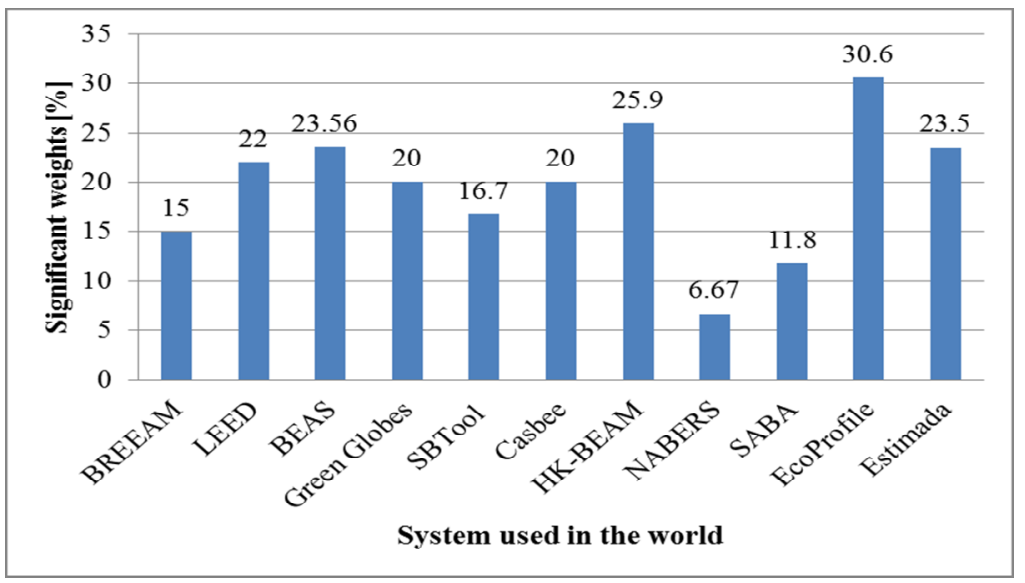

Fig. 1. Significant weights in percentage of main field in system used over the world related to IEQ

Rys. 1. Znaczące wagi działów w głównym zakresie w systemie używanym na całym świecie odnośnie do IEQ 


\section{Conclusions}

The building environmental assessment of green buildings is now a much valued sustainable development tools for evaluation of buildings for their environmental credential, for social, economic and environmental factors in many countries. Buildings should be a safe haven for people's living and therefore the "Health and Wellbeing" issues should be very important factors for any development of sustainable buildings [14]. This study provides an overview of sustainability assessment systems for rating of indoor environmental quality. The percentage weights of IEQ in presented systems vary from $6.67 \%$ to $30.6 \%$, the lowest significant weight of $6.67 \%$ is for SABA and the highest of $30.6 \%$ is for EcoProfile.

\section{Acknowledgement}

This study was supported by the Grant Agency of Slovak Republic (1/0405/13).

\section{Bibliography}

[1] Assimakopoulos, M.N. et al.: Indoor air quality in a metropolitan area metro using fuzzy logic assessment system. Science of the Total Environment, vol. 449, 2013, pp. 461-469,

[2] Sowlat et al.: A novel, fuzzy-based air quality index (FAQI) for air quality assessment. Atmospheric Environment, vol. 45, 2011, pp. 2050-2059,

[3] Lopez, A., Mathers, C., Ezzati, M., Jamison, D., Murray, C., 2006. Global Burden of Disease and Risk Factors. Oxford University Press and The World Bank, Washington DC 20433. 506. http://www.ncbi.nlm.nih.gov/books/ [access: 30 April 2015].

[4] Burgos S, Ruiz,P. \& Koifman, R.: Changes to indoor air quality as a result of relocating families from slums to public housing. Atmospheric Environment, vol. 70, 2013, pp. 179-185,

[5] Byrne, M., 1998. Aerosol exposed. Chemistry in Britain. August

[6] Jone N.C., Thornton C.A., Mark D., \& Harrison R.M.: Indoor/outdoor relationships of particulate matter in domestic homes with roadside, urban and rural locations. Atmospheric Environment, vol. 34, 2006, pp. 2603-2612,

[7] Bluyssen, P.M. (2013). Understanding the indoor environment. Inaugural speech. $\mathrm{http} / / \mathrm{www}$. google.sk/url?sa $=\mathrm{t} \& \mathrm{rct}=\mathrm{j} \& \mathrm{q}=\& \mathrm{esrc}=\mathrm{s} \&$ source $=$ web\&cd $=2 \& \mathrm{ved}=0 \mathrm{CDo}$ QFjAB\&url=http\%3A\%2F\%2Frepository.tudelft.nl\%2Fassets\%2Fuuid\%3A93a2f03 b-0fad-427a-b738-cfddb714aa07\%2F295730.pdf\&ei=2j3yUvGpNoOuygPn4LAAQ\&usg=AFQjCNGRAJY1Mk1j9ZdCFQK8h17QfJd5oQ\&sig2=LzyxdB7Xg _ AbOLevzaWQvA\&bvm=bv.60799247,d.bGQ. [access: 30 April 2015].

[8] Berardi U.: Sustainability assessment in the Construction Setctor: Rating System and Rated Buildings. Sustainable Development, 2011;

[9] Sustainable by the WBDG Sustainable Committee. Available on internet: http://www.wbdg.org/design/sustainable.php [access: 30 April 2015]. 
[10] Vierra S. Green Building Standards and Certification systems. [online], Available on internet: http://www.wbdg.org/resources/gbs.php [access: 30 April 2015].

[11] Kridlova Burdova E, Vilcekova S.: Energy performance indicators developing. Energy Procedia, vol. 14, pp. 1175-1180,

[12] Kridlova Burdova E., Vilcekova S.: Building environmental assessment system in Slovakia. Saarbrücken: LAP LAMBERT Academic Publishing, 2013, 114 p.

[13] BREEAM. Code for Sustainable Homes. Technical Guide. Department for Communities and Local Government. April 2008. www.communities.gov.uk [access: 30 April 2015].

[14] Chuck W. F., Yua Jeong Tai Kim: Building Environmental Assessment Schemes for Rating of IAQ in Sustainable Buildings. Indoor and Built Environment, vol. 20, issue 1, 2011, pp. 5-15.

[15] LEED 2009 for new construction and major renovations. For public use and display. USGBC Member Approved November 2008 (Updated November 2011), p. 117

[16] Hendrik S.: What impact could building rating tools have in helping to drive more sustainable building practice in Ireland? Thesis for MSc Architecture: AEES, University of East London, 2012;

[17] Hourigan, N.: The Development of a Building Environmental Assessment Method for Ireland. MArchSc thesis in the School of Architecture, Landscape and Civil Engineering, University College Dublin. Available in UCD Architectural Library, 2009 ,

[18] Mateus, R., Bragança, L.: Sustainability assessment and rating of buildings: Developing the methodology SBTool PT-H. Building and Environment, vol. 46, 2011, pp. 1962-1971;

[19] Ncube M., Riffat S.: Developing an indoor environment quality tool for assessment of mechanically ventilated office buildings in the UK - A preliminary study. Building and Environment, vol. 53, 2012, pp. 26-33,

[20] Lai A.C.K., Mui K.W., Wong L.T., Law, L.Y.: An evaluation model for indoor environmental quality (IEQ) acceptance in residential buildings. Energy and Buildings, vol. 41, 2009, pp. 930-936,

[21] Marino C, Nucara A., Pietrafesa, M.: Proposal of comfort classification indexes suitable for both single environments and whole buildings. Building and Environment, vol. 57, 2012, pp. 58-67,

[22] Heinzerling D. Schiavon S., Webster T., Arens E.: Indoor environmental quality assessment models: A literature review and a proposed weighting and classification scheme. Building and Environment, vol. 70, 2013, pp. 210-222,

[23] Raslanas S., Stasiukynas A., Jurgelaityte, E.: Sustainability Assessment Studies of Recreational Buildings. Procedia Engineering, vol. 57, 2013, pp. 929 - 937,

[24] Sharifi, A., Murayama, A.: Neighborhood sustainability assessment in action: Cross-evaluation of three assessment systems and their cases from the US, the UK, and Japan. Building and Environment, vol. 72, 2014, pp. 243-258, 


\section{OCENA JAKOŚCI ŚRODOWISKA WEWNATRZ BUDYNKÓW W SYSTEMACH OCENY ŚRODOWISKOWEJ BUDYNKÓW}

\section{Streszczenie}

Jakość środowiska wnętrza budynku (IEQ) ma duży wpływ na zdrowie i dobre samopoczucie użytkowników. W celu utrzymania akceptowalnego stanu IEQ, zostały przedstawione strategie, polityki, i wytyczne co do osiągania wymaganego IEQ. Wykazano potrzebę kontrola i oceny czynników lotniczych wewnątrz budynku dla zapewniania wystarczającej jakości powietrza. Przy oszacowaniu jakości środowiska wnętrza budynku, przy określaniu stopnia czystości powietrza, powinny być wzięte pod uwagę również wpływy emisji materiałów budowlanych, wyposażenia $i$ systemów HVAC. W wielu systemach przykłada się duży nacisk na oszacowanie jakość środowiska wewnętrznego na trwałości budynków. W artykule przedstawiono przegląd systemów oceny trwałości oszacowania jakości środowiska wnętrza budynku. Zaprezentowano kryteria zamieszczone w LEED, BREEAM i innych dobrze znanych systemach określających jakość środowiska wnętrza. Zaprezentowano również system oceny środowiska w budynkach (BEAS) przygotowany do zastosowania na Słowacji. Systemy oceny, używane na świecie są oparte o podobne systemy BEAS. Są to wielokryterialne systemy obejmujące sześć głównych obszarów takich jak wybór miejsca i projektu; konstrukcję budynku; środowisko wewnętrzne; wydajność energetyczną; zarządzanie wodą i odpadami. System ten składa się z oceny 53 wskaźników.

Słowa kluczowe: środowisko wewnątrz budynku, ocena trwałości budynków, BEAS

Przestano do redakcji:30.05.2015

Przyjęto do druku:10.01.2016

DOI: $10.7862 / \mathrm{rb} .2015 .210$ 